\title{
ВИВЧЕННЯ ГОСТРОЇ ТОКСИЧНОСТІ ТА ПРОТИЗАПАЛЬНОЇ АКТИВНОСТІ СПИРТОВИХ ЕКСТРАКТІВ ТРАВИ СНУ БІЛОГО (PULSATILA ALBA)
}

\author{
О. С. Хропот ${ }^{1}$, Ю. Т. Конечнийㄹ, Ю. І. Колб${ }^{1}$, Р. Т. Конечна ${ }^{1}$, І. І. Губицька ${ }^{1}$,

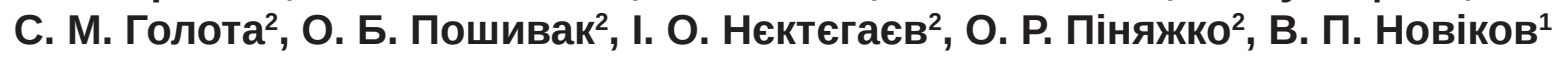 \\ Національний університет «Львівська політехніка» ${ }^{1}$, Львів \\ Львівський національний медичний університет імені Данила Галицького ${ }^{2}$ \\ Lvov.mp@gmail.com
}

ІНФОРМАЦІЯ

Надійшла до редакції / Received: 06.05.2019

Після доопрацювання / Revised: 08.05.2019

Прийнято до друку / Accepted: 27.05.2019

\section{Ключові слова}

сон білий;

Pulsatila alba;

гостра токсичність;

протизапальна активність;

карагеніновий набряк.
АНОТАЦІЯ

Мета роботи. Дослідження гострої токсичності та протизапальної (антиексудативної) активності спиртових екстрактів трави сну білого (Pulsatila alba).

Матеріали і методи. Дослідження гострої токсичності проведено на 78 безпородних білих щурах обох статей масою 190-220 г, яким вводили тестовані спиртові екстракти трави сну білого (Pulsatila alba) одноразово внутрішньошлунково за допомогою металевого зонда в дозах 5000, 10000 та 15000 мг/кг. Для вивчення антиексудативної активності використовували карагенінову модель запального набряку задньої лапи білих щурів (42 тварини). Досліджувані екстракти вводили внутрішньошлунково в дозі 2 мл/кг. Як препарати порівняння використовували диклосренак натрію та кеторолаку трометаміну.

Результати й обговорення. Результати вивчення гострої токсичності екстрактів трави сну білого (Pulsatila alba) свідчать про відсутність будьяких токсичних проявів при внутрішньошлунковому введенні в дозах 5000, 10000 та 15000 мг/кг на білих щурах, що дозволяє віднести їх до VI класу токсичності (відносно нешкідливі речовини). Спиртові екстракти трави сну білого проявляють протизапальну активність на карагеніновій моделі запального набряку лапи білого щура і фрармакологічний ефект залежить від концентрації етанолу та співвідношення сировина:екстрагент. Найкращу антиексудативну активність проявляє 70 \% спиртовий екстракт (1:20), показник пригнічення запальної реакції якого становив $27 \%$, що дещо поступається ресреренс-препаратам (на 10 та $17 \%$ відносно кеторолаку трометаміну та диклосренаку натрію, відповідно) та є хорошим показником для рослинних протизапальних засобів.

Висновки. Досліджено гостру токсичність та протизапальну дію спиртових екстрактів трави сну білого (Pulsatila alba) і встановлено, що 70 \% спиртовий екстракт (1:20) є відносно нешкідливою речовиною (VI клас токсичності) та проявляє виразну протизапальну активність (показник пригнічення запальної реакції = 27 \%) на карагеніновій моделі запального набряку лапи білого щура при внутрішньошлунковому введенні.

ISSN 2312-0967. Фармацевтичний часопис. 2019. № 2 
Вступ. Препарати на основі лікарської рослинної сировини, які проявляють протизапальні властивості, широко застосовують як допоміжні та профрілактичні засоби в педіатрії, стоматології, гінекології, проктології та інших галузях медицини [1]. Аналіз орармацевтичного ринку України дозволяє стверджувати, що популярність рослинних лікарських засобів у динаміці зростає. Серед всіх зареєстрованих лікарських засобів готові лікарські препарати рослинного походження посідають близько 10 \% ринку [2]. Популярність фотопрепаратів для терапії патологічних процесів пояснює ряд фракторів: комплексний вплив на організм, що включає нормалізацію вітамінного балансу, корекцію обмінних та імунологічних порушень на клітинному рівні тощо; низьку токсичність, а також багаторічний досвід застосування в неофіциальній медицині. Рослини роду Сон (Pulsatilla) характеризуються вмістом широкого спектра біологічно важливих та активних органічних сполук: тритерпеноїди, сапоніни, стероїди, лактони, цукри та алкалоїди $[3,4]$. В науковій літературі зустрічаються дані щодо використання вищезгаданих рослин в народній медицині та гомеопатії $[5,6]$. У роботі досліджено гостру токсичність та протизапальну (антиексудативну) активність спиртових екстрактів сну білого (Pulsatila alba).

Матеріали і методи. Для дослідження використовували спиртові екстракти сну білого (Pulsatila alba) 3 різною концентрацією етанолу та співвідношенням сировина:екстрагент під кодовими назвами С-2 (40\%, 1:20), C-3 (70 \%, 1:20), C-12 (40\%, 1:10), C-13 (70\%, 1:10) [7]. Експериментальних тварин утримували у стандартних умовах віварію згідно з санітарно-гігієнічними нормами на стандартному раціоні та стандартизованих за фрізіологічними та біохімічними показниками. При проведенні експериментальних досліджень тварини перебували у звичайних умовах згідно з нормами і принципами Директиви Ради ЄС 3 питань захисту хребетних тварин, яких використовують для експериментальних та інших наукових досліджень [8, 9].

Дослідження гострої токсичності проведено на 60 безпородних білих щурах обох статей масою 190220 г [10]. Перед експериментом тварин поділили на 10 груп по 6 тварин у кожній групі. За 24 год до введення препаратів на основі екстрактів щурів не годували. Тестовані екстракти вводили одноразово внутрішньошлунково за допомогою металевого зонда в дозах 5000, 10000 та 15000 мг/кг. Кожна група тварин отримувала по одній дозі одного виду екстракту і одна група щурів (n=6) слугувала інтактною. Після введення препаратів тварин утримували ще 4 год без їжі 3 вільним доступом до води. При виборі дози під час вивчення гострої токсичності за умов внутрішньошлункового введення орієнтувались на максимальну дозу IV класу токсичності - 5000 мг/кг відповідно до методичних рекомендацій [11]. Спостере- ження за тваринами проводили протягом двох тижнів. Реєстрували прояви порушень фрізіологічного стану щурів, виживаність, динаміку маси тіла. Під час експерименту тварин утримували на звичайному раціоні з вільним доступом до води та їжі.

Для вивчення антиексудативної активності використовували карагенінову модель запального набряку задньої лапи білих щурів [12]. Для досліду використано 42 щурів-самців альбіносів масою 180-220 г. Відібрані тварини рандомізовані методом випадкової вибірки розділені на 7 груп по шість у кожній. Розчин карагеніну 1,0 \% (в стерильному 0,9% NaCl) вводили підшкірно в субпланарну область задньої лапи (0,1 мл для кожної лапи) через 1 год після введення досліджуваних екстрактів. Тестовані екстракти вводили внутрішньошлунково, в дозі 2 мл/кг. Як референс-препарати використовували диклофенак натрію (8 мг/кг), кетанов (10 мг/кг), які вводили внутрішньошлунково. Об'єм задньої лапи вимірювали за допомогою електронного онкографра безпосередньо перед і через 4 год після ін'єкції карагеніну. Антиексудативну активність (AEA) розраховували як зменшення набряку лапи щурів, розраховували за допомогою рівняння і виражали у відсотках:

$$
\text { AEA, } \%=\Delta \mathrm{V} \text { контроль }-\Delta \mathrm{V} \text { дослід } \times 100 \%
$$

де, $\Delta$ Уконтроль і $\Delta$ Удослід - середні значення різниці об'ємів задньої лапи для контрольних та дослідних тварин, відповідно.

Отримані цифрові дані піддавали статистичній обробці з використанням t-критерію Ст'юдента з використанням пакета програм «Microsoft Excel». Результати представлені у вигляді $\mathrm{M} \pm \mathrm{m}$, де $\mathrm{M}$ - вибіркове середнє, m - помилка середнього. Зміни вважали статистично значущими при $p<0,05$.

Результати й обговорення. Після внутрішньошлункового введення препарату в дозі 5000 мг/кг ознак інтоксикації у щурів не спостерігали: тварини були охайні, активні, мали задовільний апетит, реагували на звукові та світлові подразники, процеси сечовиділення і десрекації були в нормі, порушення дихання та судом не спостерігали. Рефрлекторна збудливість у всіх тварин була збережена. Відразу після введення досліджуваних екстрактів у дозах 10000 та 15000 мг/кг спостерігали нетривалу рухову загальмованість тварин, вочевидь, пов'язану з перевантаженням шлунка значним об'ємом рідини, чого не спостерігали при введенні в дозі 5000 мг/кг. В подальшому змін у зовнішньому вигляді, стані покривів тіла та динаміці маси тіла не спостерігали. При спостереженні за тваринами протягом 2 тижнів не встановлено загибелі в жодній 3 експериментальних груп (табл. 1). Порівняння поведінки щурів, споживання води та їжі піддослідними й інтактними тваринами показало відсутність відмінностей.

Результати вивчення гострої токсичності екстрактів С-2, С-3, С-12, С-13 свідчать про відсутність

ISSN 2312-0967. Pharmaceutical review. 2019. № 2 
Фармакологічні дослідження біологічно активних речовин Pharmacological researches of biologically active substances

\section{Таблиця 1}

Результати дослідження гострої токсичності екстрактів C-2, C-3, C-12, C-13 при внутрішньошлунковому шляху

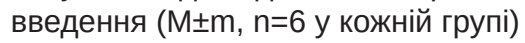

\begin{tabular}{|c|c|c|c|c|c|c|}
\hline \multirow{2}{*}{ Групи/показники } & \multirow{2}{*}{ Доза, мг/кг } & \multirow{2}{*}{$\mathrm{N} / \mathrm{N}^{\prime}$} & \multicolumn{4}{|c|}{ Маса тварин, г } \\
\hline & & & Вихідні дані & 3 день & 7 день & 14 день \\
\hline Інтактні тварини & - & $0 / 6$ & $193,3 \pm 4,1$ & $196,3 \pm 2,1$ & $200,8 \pm 3,3$ & $211,9 \pm 3,2$ \\
\hline \multirow{3}{*}{$\begin{array}{c}40 \text { \% спиртовий екстракт } \\
\text { (1:20) Pulsatila alba C-2 }\end{array}$} & 5000 & $0 / 6$ & $191,5 \pm 3,2$ & $194,5 \pm 3,3$ & $201,5 \pm 4,1$ & $212,5 \pm 3,9$ \\
\hline & 10000 & $0 / 6$ & $196,4 \pm 3,1$ & $198,2 \pm 2,4$ & $202,4 \pm 4,0$ & $212,4 \pm 4,0$ \\
\hline & 15000 & $0 / 6$ & $194,3 \pm 2,8$ & $198,3 \pm 2,8$ & $201,3 \pm 3,5$ & $210,9 \pm 3,8$ \\
\hline \multirow{3}{*}{$\begin{array}{c}70 \text { \% спиртовий екстракт } \\
\text { (1:20) Pulsatila alba C-3 }\end{array}$} & 5000 & $0 / 6$ & $192,5 \pm 2,2$ & $197,1 \pm 3,0$ & $200,6 \pm 4,2$ & $211,6 \pm 4,5$ \\
\hline & 10000 & $0 / 6$ & $193,5 \pm 2,3$ & $198,7 \pm 3,5$ & $202,3 \pm 3,5$ & $213,1 \pm 3,3$ \\
\hline & 15000 & $0 / 6$ & $190,6 \pm 3,1$ & $195,8 \pm 3,1$ & $199,9 \pm 2,8$ & $210,5 \pm 3,7$ \\
\hline \multirow{3}{*}{$\begin{array}{l}40 \text { \% спиртовий екстракт } \\
(1: 10) \text { Pulsatila alba C-12 }\end{array}$} & 5000 & $0 / 6$ & $192,8 \pm 2,4$ & $197,2 \pm 2,8$ & $201,8 \pm 2,9$ & $212,7 \pm 3,5$ \\
\hline & 10000 & $0 / 6$ & $194,4 \pm 4,1$ & $199,0 \pm 3,3$ & $203,8 \pm 4,0$ & $216,3 \pm 3,0$ \\
\hline & 15000 & $0 / 6$ & $191,8 \pm 3,4$ & $197,7 \pm 3,2$ & $202,5 \pm 3,2$ & $212,9 \pm 4,2$ \\
\hline \multirow{3}{*}{$\begin{array}{l}70 \text { \% спиртовий екстракт } \\
\text { (1:10) Pulsatila alba C-13 }\end{array}$} & 5000 & $0 / 6$ & $190,9 \pm 4,0$ & $197,1 \pm 3,4$ & $203,5 \pm 2,8$ & $214,9 \pm 4,6$ \\
\hline & 10000 & $0 / 6$ & $195,4 \pm 4,1$ & $201,3 \pm 3,1$ & $206,8 \pm 3,4$ & $219,3 \pm 3,5$ \\
\hline & 15000 & $0 / 6$ & $193,3 \pm 3,3$ & $197,2 \pm 2,9$ & $201,4 \pm 3,3$ & $213,2 \pm 3,3$ \\
\hline
\end{tabular}

Примітки: N/N' - кількість загиблих тварин / кількість тварини, які вижили.

будь-яких токсичних проявів при внутрішньошлунковому введенні в дозах 5000, 10000 та 15000 мг/кг на білих щурах, що дозволяє віднести їх до VI класу токсичності (відносно нешкідливі речовини) [13].

При аналізі отриманих результатів in vivo антиексудативної активності екстрактів встановлено, що спиртові екстракти трави сну білого (Pulsatila alba) характеризуються різним впливом на перебіг асептичного запального процесу кінцівки лапи білих щурів індукованого карагеніном (табл. 2, рис. 1), проте фрармакологічний ефект залежить від концентрації етанолу та співвідношення сировина:екстрагент.

Серед тестованих екстрактів найкращий рівень протизапальної активності продемонстрував $70 \%$ спиртовий екстракт (1:20) C-3, показник пригнічення запальної реакції якого становив 27 \%, що дещо по- ступається редеренс-препаратам (на 10 та $17 \%$ кетанов та диклофенаку натрію, відповідно) та $є$ хорошим показником для рослинних протизапальних засобів.

Тенденція до виразної протизапальної активності спостерігалася також і у 70 \% спиртового екстракту (1:10) C-13, проте показник пригнічення його запальної реакції був дещо нижчий і становив 12,6 \%. Тоді як $40 \%$ спиртовий екстракт (1:20) С-2 практично не виявив значимого антиексудативного ефекту (показник пригнічення запальної реакції становить 1,83 \%). Досліджуваний екстракт (1:10) C-12 проявив фологогенні властивості та сприяв розвитку запального процесу.

Таким чином, проведені дослідження дають можливість встановити, що водно-спиртові екстракти трави сну білого (Pulsatila alba) за величиною ЛД50

\section{Таблиця 2}

In vivo антиексудативна активність екстрактів C-2, C-3, C-12, C-13 на карагеніновій моделі запального набряку лапи білих щурів $(\mathrm{M} \pm \mathrm{m}, \mathrm{n}=6)$

\begin{tabular}{|c|c|c|c|}
\hline Групи / параметри & Дози & $\begin{array}{c}\text { Збільшення об'єму } \\
\text { лапи щурів, 4 год, \% }\end{array}$ & $\begin{array}{c}\text { Пригнічення } \\
\text { запалення, \% (АЕА) }\end{array}$ \\
\hline Контроль «Модельна патологія» & - & 125,5 & 44,1 \\
\hline Диклосренак натрію & 8,0 мг/кг & 70,1 & 36,9 \\
\hline Кетанов & 10,0 мг/кг & 79,2 & 1,83 \\
\hline 40 \% спиртовий екстракт (1:20) Pulsatila alba C-2 & 2 мл/кг & 123,2 & 27,0 \\
\hline 70 \% спиртовий екстракт (1:20) Pulsatila alba C-3 & 2 мл/кг & 91,6 & $-4,4$ \\
\hline 40 \% спиртовий екстракт (1:10) Pulsatila alba C-12 & 2 мл/кг & 131,0 & 12,6 \\
\hline 70 \% спиртовий екстракт (1:10) Pulsatila alba C-13 & 2 мл/кг & 109,7 & \\
\hline
\end{tabular}

ISSN 2312-0967. Фармацевтичний часопис. 2019. № 2 
Фармакологічні дослідження біологічно активних речовин Pharmacological researches of biologically active substances

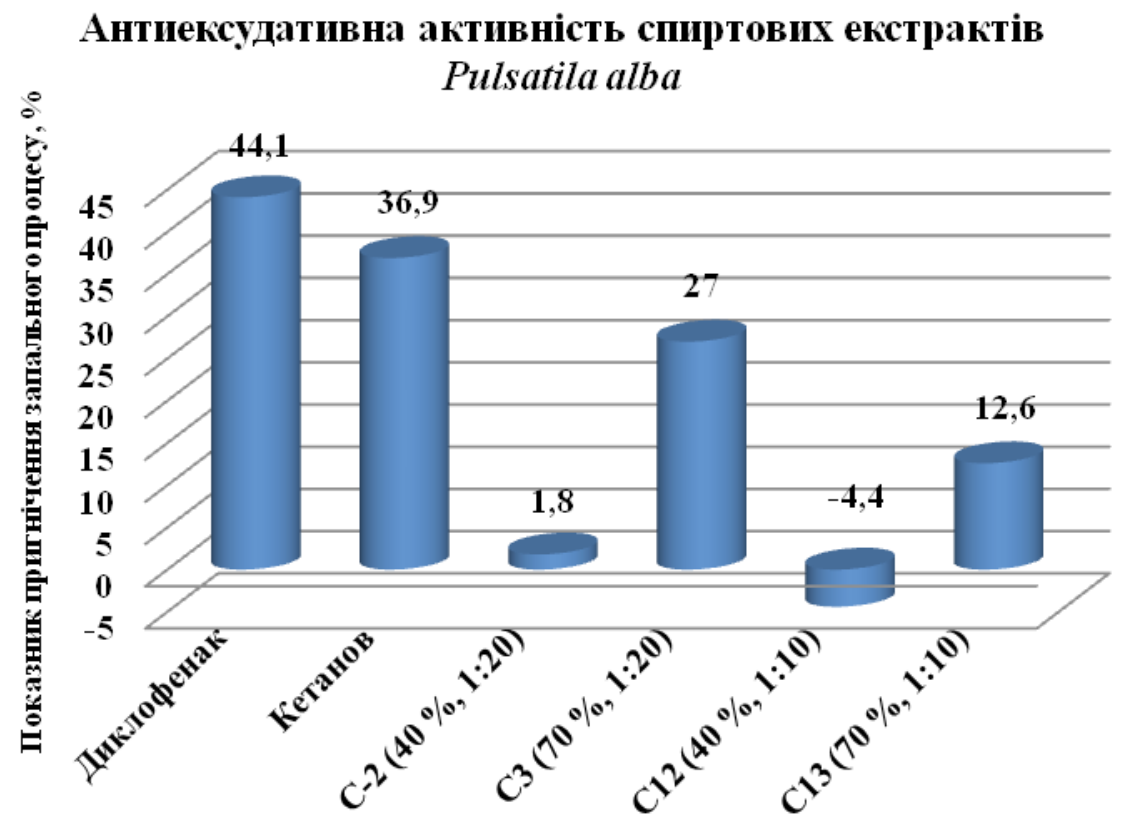

Рис. 1. In vivo антиексудативна активність екстрактів C-2, C-3, C-12, C-13 на карагеніновій моделі запального набряку лапи білих щурів.

при внутрішньошлунковому введенні є практично нетоксичними речовинами, та виявити їх протизапальні властивості. При цьому за рівнем протизапальної активності всі досліджувані рослинні екстракти поступаються нестероїдним протизапальним лікарським засобам диклофенаку натрію та кеторолаку. Проте 70 \% спиртовий екстракт (1:20) трави сну білого (Pulsatila alba) у дозі 2 мл/кг при внутрішньошлунковому введенні проявляє потенційну протизапальну активність, яка несуттєво поступається ефректам рефреренс-препаратів та може бути рекомендований для поглибленого фрармакологічного дослідження як компонента комбінованого протизапального фрітозасобу. Отримані дані демонструють перспективність подальшого дослідження спектра біологічної активності водноспиртових екстрактів надземної частини сну білого (Pulsatila alba).
Висновки. 1. Досліджено гостру токсичність та протизапальну дію спиртових екстрактів трави сну білого (Pulsatila alba).

2. Встановлено, що за показниками гострої токсичності екстракти трави сну білого (Pulsatila alba) при внутрішньошлунковому введенні $€$ відносно нешкідливими речовинами (VI клас токсичності).

3. Встановлено, що $70 \%$ спиртовий екстракт (1:20) трави сну білого (Pulsatila alba) у дозі 2 мл/кг при внутрішньошлунковому введенні проявляє потенційну протизапальну активність, яка несуттєво поступається ефректу класичного протизапального лікарського засобу диклофенаку натрію, та може бути рекомендований для поглибленого фрармакологічного дослідження як компонента комбінованого фрітозасобу.

Конфлікт інтересів: відсутній.

Conflicts of interest: authors have no conflict of interest to declare.

\section{ИЗУЧЕНИЕ ОСТРОЙ ТОКСИЧНОСТИ И ПРОТИВОВОСПАЛИТЕЛЬНОЙ АКТИВНОСТИ СПИРТОВЫХ ЭКСТРАКТОВ ТРАВЫ СНА БЕЛОГО (PULSATILA ALBA)}

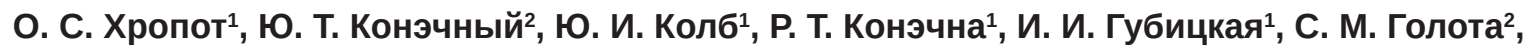
О. Б. Пошывак ${ }^{2}$, И. О. Нектегаев ${ }^{2}$, О. Р. Пиняжко ${ }^{2}$ В. П. Новиков ${ }^{1}$

Национальный университет «Львовская политехника» ${ }^{1}$, Львов

Львовский национальный медицинский университет имени Данила Галицкого 2

Lvov.mp@gmail.com

Цель работы. Исследования острой токсичности и противовоспалительной (антиэкссудативной) активности спиртовых экстрактов травы сна белого (Pulsatila alba).

ISSN 2312-0967. Pharmaceutical review. 2019. № 2 
Фармакологічні дослідження біологічно активних речовин Pharmacological researches of biologically active substances

Материалы и методы. Исследование острой токсичности проведены на 60 беспородных белых крысах обоего пола массой 190-220 г, которым вводили тестируемые экстракты однократно внутрижелудочно с помощью металлического зонда в дозах 5000, 10000 и 15000 мг/кг. Для изучения антиэкссудативной активности использовали карагениновую модель воспалительного отека задней лапы белых крыс. Тестированные экстракты вводили внутрижелудочно в дозе 2 мл/кг. Как препараты сравнения использовали диклофенак натрия и кетанов.

Результаты и обсуждение. Результаты изучения острой токсичности экстрактов травы сна белого (Pulsatila alba) свидетельствуют об отсутствии каких-либо токсических проявлений при внутрижелудочном введении в дозах 5000, 10000 и 15000 мг/кг белых крысах, что позволяет отнести их к VI классу токсичности (относительно безвредные вещества). Спиртовые экстракты травы сна белого (Pulsatila alba) обладают тенденцией к проявлению противовоспалительной активности на карагениновой модели воспалительного отека лапы белой крысы и фармакологический эффрект зависит от концентрации этанола и соотношения сырье:экстрагент. Лучшее антиэкссудативное действие продемонстрировал 70 \% спиртовой экстракт (1:20), показатель подавления воспалительной реакции которого составил $27 \%$, что несколько уступает ресеренс-препаратам (на 10 и $17 \%$ относительно кетанова и диклофенака натрия, соответственно) и является хорошим показателем для растительных противовоспалительных средств.

Выводы. Исследована острая токсичность и противовоспалительное действие спиртовых экстрактов травы сна белого (Pulsatila alba) и установлено, что 70 \% спиртовой экстракт (1:20) является относительно безвредным веществом (VI класс токсичности) и обладает выраженной противовоспалительной активностью (показатель подавления воспалительной реакции = 27 \%) на карагениновий модели воспалительного отека лапы белой крысы при внутрижелудочном введении.

Ключевые слова: сон белый; Pulsatila alba; острая токсичность; противовоспалительная активность; карагениновий отек.

\title{
STUDYING OF ACUTE TOXICITY AND ANTI-INFLAMMATORY ACTIVITY OF PULSATILA ALBA ETHANOLIC EXTRACTS
}

\author{
O. S. Khropot ${ }^{1}$, Yu. T. Konechnyi², Y. I. Kolb ${ }^{1}$, R. T. Konechna ${ }^{1}$, I. I. Hubytska ${ }^{1}$, S. M. Holota ${ }^{2}$, \\ O. B. Poshyvak², I. O. Nektehaev², O. R. Pinyazhko², V. P. Novikov ${ }^{1}$ \\ ${ }^{1}$ Lviv Polytechnic National University \\ ${ }^{2}$ Danylo Halytsky Lviv National Medical University \\ Lvov.mp@gmail.com
}

The aim of the work. Research of the acute toxicity and anti-inflammatory (anti-exudative) activity studying of Pulsatila alba ethanolic extracts.

Materials and Methods. Acute toxicity studies were performed on 60 white rats of both sexes weighing 190-220 g, which were administered intragastric single-dose of tested extracts at doses of 5000, 10,000 and 15,000 mg/kg. The carragenine model of inflammatory oedema of white rats paw was used for anti-exudative activity studying. The tested extracts were administered intragastrically at a dose of $2 \mathrm{ml} / \mathrm{kg}$. Diclofenac sodium and ketanov were used as reference drugs.

Results and Discussion. The results of Pulsatila alba ethanolic extracts acute toxicity studying demonstrated absence of any toxic manifestations in intragastric administration at doses of 5000,10,000 and 15,000 mg/kg in white rats, which allows their to VI class of toxicity (relatively harmless substances). The Pulsatila alba ethanolic extracts posses a tendency for anti-inflammatory activity in the carrageenan model of inflammatory edema in white rats and the pharmacological effect depends on the concentration of ethanol and the ratio of raw material: extractant. The best anti-exudative activity was detected for $70 \%$ ethanolic extracts (1:20), an inhibition index of inflammatory response was $27 \%$, which is slightly inferior to reference drugs (by 10 and $17 \%$ relative ketanov and sodium diclofenac, respectively) and is a good level for anti-inflammatory phitopreparations.

Conclusions. The acute toxicity and anti-inflammatory effect of Pulsatila alba ethanolic extracts were investigated and it was established that $70 \%$ alcoholic extract (1:20) is a relatively harmless substance (grade VI toxicity) and has potency anti-inflammatory activity (inhibition of inflammation $=27 \%$ ) on the carrageenan model of inflammatory edema of the white rat paws at intragastric administration.

Keywords: Pulsatila alba; acute toxicity; anti-inflammatory activity; carrageenan oedema.

ISSN 2312-0967. Фармацевтичний часопис. 2019. № 2 


\section{Список літератури}

1. Medicinal plants with anti-inflammatory activities / F. Maione, R. Russo, H. Khan, N. Mascolo // Nat. Prod. Res. - 2016. - Vol. 30 (12). - P. 1343-1352. doi:10.108 0/14786419.2015.1062761.

2. Гудзенко А. В. Вітчизняний ринок багатокомпонентних лікарських засобів рослинного походження: аналіз стану структура та перспективи розвитку / А. В. Гудзенко, О. О. Цуркан, Т. В. Ковальчук // Фармац. журнал. - 2012. - № 1. - С. 8-12.

3. Cao P. Advances in the studies on the chemical constituents and biologic activities for Anemone species / P. Cao, F. E. Wu, L. S. Ding // Nat. Prod. Res. Dev. -2004. - Vol. 6. - P. 581-584. doi:10.3969/j.issn.10016880.2004.06.024

4. Zou Z. J. Phytochemical components and pharmacological activities of the genus Anemone / Z. J. Zou, H. X. Liu, J. S. Yang // Chin. Pharm. J. - 2004. - Vol. 39. - Р. 493-495.

5. Анемонадібровна. Anemonenemorosa L. Аналітичний огляд / А. Лук'янчук, О. Хропот, Ю. Конечний [та ін.] // ScienceRise: Pharmaceutical Science. - 2017. - T.3 (7). - C. 38-42. doi:10.15587/2519-4852.2017.104438

6. Agrawal T. Anemone Pulsatilla a useful drug plant / T. Agrawal // Biomed. J. Sci. Tech. Res. - 2018. Vol. (3). - P. 1-2. doi:10.26717/BJSTR.2018.08.001658

7. Research of antioxidant properties of extracts of the plants and the callus biomass / R. Konechna, O. Khro-

\section{References}

1. Maione F, Russo R, Khan H, Mascolo N. Medicinal plants with anti-inflammatory activities. Nat. Prod. Res. 2016;30(12): 1343-52. doi:10.1080/14786419.2015.10 62761.

2. Hudzenko AV, Curkan OO, Kovalchuk TV. [Domestic market of multicomponent herbal medicinal products: analysis of the state of the structure and development prospects]. Farmats zhurn., 2012;1: 8-12. [Ukrainian].

3. Cao P, Wu FE, Ding LS. Advances in the studies on the chemical constituents and biologic activities for Anemone species. Nat Prod Res Dev. 2004;16: 581-4. doi:10.3969/j.issn.1001-6880.2004.06.024

4. Zou ZJ, Liu HX, Yang JS. Phytochemical components and pharmacological activities of the genus Anemone. Chin Pharm J. 2004;39: 493-5.

5. Lukianchuk A, Khropot O, Konechnyi Yu, Konechna R, Novikov V. Anemone nemorosa L. Analytical review. ScienceRise: Pharm. Sci. 2017;3(7): 38-42. doi:10.15587/2519-4852.2017.104438 Ukrainian.

6. Agrawal T. Anemone Pulsatilla a useful drug plant. Biomed J Sci Tech Res. 2018;8(3): 1-2. doi:10.26717/ BJSTR.2018.08.001658

7. Konechna R, Khropot O, Kurka M, Petrina R, Gubriy Z, Novikov V. Research of antioxidant properties of pot, M. Kurka [et al.] // Asian. J. Pharm. Clin. Res. -2017. - Vol. 10 (7). - P. 182-185. doi:10.22159/ajpcr.2017.v10i7.18408

8. European convention for the protection of vertebrate animals used for experimental and other scientific purpose. - Strasburg, Council of Europe, Publication and Documents Division. - Printed in France. - Edition November; 1987.

9. Етика лікаря та права людини: положення про використання тварин у біомедичних дослідах // Експеримент. та клін. фріз. і біохімія. - 2003. - № 2 (22). - C. 108-109.

10. Litchfield J. T. A simplified method of evaluating doseeffect experiments / J. T. Litchfield, F. Wilcoxon // J. Pharmacol. Exp. Ther. -1949. - Vol. 96. - P. 99.

11. Доклінічні дослідження лікарських засобів : метод. рек. / За ред. О. В. Стефранова. - К. : “Авіцена”, 2001. $-528 \mathrm{c}$.

12. Winter C. A. Carrageenin-induced edema in hind paw of the rat as an assay for antiinflammatory drugs / C. A. Winter, E. A. Risley, G. W. Nuss // Proc. Soc. Exp. Biol. Med. - 1962. -Vol. 111 (3). - P. 544-547.

13. Сидоров К. К. О класификации токсичности ядов при парэнтеральном способе введения / К. К. Сидоров // Токсикология новых промышленных химических веществ. - М. : Медицина. - 1973. Вып. 13. - С. 47-51.

extracts of the plants and the callus biomass. Asian $\mathrm{J}$ Pharm Clin Res. 2017;10(7): 182-5. doi:10.22159/ajpcr.2017.v10i7.18408

8. European convention for the protection of vertebrate animals used for experimental and other scientific purpose. Strasburg, Council of Europe, Publication and Documents Division. Printed in France. Edition November; 1987.

9. [Ethics of a doctor and human rights: provisions on the use of animals in biomedical experiments]. Eksperyment i klin fiz i biokhim. 2003;2(22): 108-9. in Ukrainian.

10. Litchfield JT, Wilcoxon F. A simplified method of evaluating dose-effect experiments. J Pharmacol Exp Ther. 1949;96: 99

11. Stefanov OV. (Ed). Preclinical studies of drugs: guidelines. [Доклінічні дослідження лікарських засобів: метод. рек.] Kyiv: 2001. Ukrainian.

12. Winter CA, Risley EA, Nuss GW. Carrageenin-induced edema in hind paw of the rat as an assay for antiinflammatory drugs. Proc Soc Exp Biol Med. 2016;111(3): 544-7.

13. Sidorov KK. Classification of the toxicity of poisons in the parenteral method of administration. [О классификации токсичности ядов при парэнтеральном способе введения] Moscow: Meditsina; 1973. Russian. 
Фармакологічні дослідження біологічно активних речовин

Pharmacological researches of biologically active substances

\section{Відомості про автора}

Хропот О. С. - аспірант кафедри технології біологічно активних сполук, фрармації та біотехнології, Національний університет «Львівська політехніка», Львів, Україна. E-mail: Lvov.mp@gmail.com, ORCID: 0000-0002-1985-3498

Конечний Ю. Т. - аспірант кафедри мікробіології, Львівський національний медичний університет імені Данила Галицького, Львів, Україна. E-mail: yuliankonechnyi@gmail.com, ORCID: 0000-0003-4789-1675

Колб Ю. І. - аспірант кафедри технології біологічно активних сполук, фрармації та біотехнології, Національний університет «Львівська політехніка», Львів, Україна. E-mail: yuliakolb212@gmail.com, ORCID: 0000-0002-1222-7056 Конечна Р. Т. - канд. фрармац. н., доцент кафедри технології біологічно активних сполук, срармації та біотехнології, Національний університет «Львівська політехніка», Львів, Україна. E-mail: rkonechna@ukr.net, ORCID: 0000-00016420-9063

Губицька І. І. - канд. хім. н., доц. кафедри технології біологічно активних сполук, фрармації та біотехнології, Національний університет «Львівська політехніка», Львів, Україна. E-mail: ihubytska@gmail.com, ORCID: 0000-00022552-0171

Голота С. М. - канд. фрармац. н., асистент кафедри фрармацевтичної, органічної і біоорганічної хімії, Львівський національний медичний університет імені Данила Галицького, Львів, Україна. E-mail: golota_serg@yahoo.com, ORCID 0000-0002-9892-437X

Пошивак О. Б. - канд. мед. н., доцент кафредри фрармакології, Львівський національний медичний університет імені Данила Галицького, Львів, Україна. E-mail: olesya.poshyvak@googlemail.com, ORCID: 0000-0001-6277-8238

Нєктєгаєв І. О. - ст. лаборант кафедри фрармакології, Львівський національний медичний університет імені Данила Галицького, Львів, Україна.

Піняжко О. Р. - д. мед. н., профресор, завідувач кафедри фрармакології, Львівський національний медичний університет імені Данила Галицького, Львів, Україна. E-mail: olehpinyazhko@gmail.com, ORCID: 0000-0002-09615656

Новіков В. П. - д. хім. н., профр., завідувач кафредри технології біологічно активних сполук, срармації та біотехнології, Національний університет «Львівська політехніка», Львів, Україна. E-mail: volodymyr.p.novikov@Ipnu.ua, ORCID: 0000-0002-0485-8720

Information about authors:

Khropot O. S. - PhD student, Department of Technology of Biologically Active Substances, Pharmacy and Biotechnology, Lviv Polytechnic National University, Lviv, Ukraine. E-mail: Lvov.mp@gmail.com, ORCID: 0000-0002-1985-3498

Konechnyi Y. T. - PhD student, Department of Microbiology, Danylo Halytsky Lviv National Medical University, Lviv, Ukraine. E-mail: yuliankonechnyi@gmail.com, ORCID: 0000-0003-4789-1675

Kolb Y.I. - PhD student, Department of Technology of Biologically Active Substances, Pharmacy and Biotechnology, Lviv Polytechnic National University, Lviv, Ukraine. E-mail: yuliakolb212@gmail.com, ORCID: 0000-0002-1222-7056

Konechna R. T. - PhD (Pharmacy), Associate Professor of the Department of Technology of Biologically Active Substances, Pharmacy and Biotechnology, Lviv Polytechnic National University, Lviv, Ukraine. E-mail: rkonechna@ukr.net, ORCID: 0000-0001-6420-9063

Hubytska I. I. - PhD (Chemistry), Associate Professor of the Department of Technology of Biologically Active Substances, Pharmacy and Biotechnology, Lviv Polytechnic National University, Lviv, Ukraine. E-mail: ihubytska@gmail.com, ORCID: 0000-0002-2552-0171

Holota S. M. - PhD (Pharmacy), Assistant of the Pharmaceutical, Organic and Bioorganic Chemistry Department, Danylo Halytsky Lviv National Medical University, Lviv, Ukraine. E-mail: golota_serg@yahoo.com, ORCID 0000-0002-9892-437X Poshyvak O. B. - PhD (Medicine), Associate Professor of the Pharmacology Department, Danylo Halytsky Lviv National Medical University, Lviv, Ukraine. E-mail: olesya.poshyvak@googlemail.com, ORCID: 0000-0001-6277-8238

Nektegaev I. O. - Senior laboratory assistant of the Pharmacology Department, Danylo Halytsky Lviv National Medical University, Lviv, Ukraine.

Pinyazhko O. R. - DS (Medicine), Professor, Chief of the Pharmacology Department, Danylo Halytsky Lviv National Medical University, Lviv, Ukraine. E-mail: olehpinyazhko@gmail.com, ORCID: 0000-0002-0961-5656

Novikov V. P. - DS (Chemistry),_Professor, Head of the Department of Technology of Biologically Active Substances, Pharmacy and Biotechnology, Lviv Polytechnic National University, Lviv, Ukraine E-mail: volodymyr.p.novikov@Ipnu.ua, ORCID: 0000-0002-0485-8720 